\title{
Communications
}

\section{Studies on the Total Synthesis of Amphidinolide O (III): A Stereoselective Synthesis of C1-C11 Fragment}

\author{
Jong Woo Kim, Sun-Ju Kong, Yeo-Jin Kim, and Duck-Hyung Lee \\ Department of Chemistry, Sogang Lniversity, Seoul 121-742, Korea. ${ }^{\circ}$ E-mail: dhlee a sogang.ackr \\ Received November 26, 2007
}

Key Words : Amphidinolide O. Cytotoxic macrolide. Stereoselective șynthesis. Brown crotỵlation

The amphidinolides are well-known series of cytotoxic macrolides isolated from the marine dinoflagellate Amphidinizm sp., a symbiotic with Okinawan marine flatworm Amphiscolops sp. These series of compounds attracted much interest of the synthetic chemists around the world. In fact. total synthesis of amphidinolide A, E. H. G J. K. P, T, W. X. and $\dot{Y}$ were reported, ${ }^{l}$ and many synthetic studies for anthidinolide B. C, F, and L, have been published. -

In relation to our program for the synthesis of amphidinolide $\mathrm{O}(1)$, which exhibited in wro cy totoxicity against $\mathrm{L} 1210$ ( $\mathrm{IC}_{50} 1.7 \mu \mathrm{g} / \mathrm{mL}$ ) and human epidermoid carcinoma $\mathrm{KB}$ cells $\left(\mathrm{IC}_{5 \mathrm{i}} 3.6 \mu \mathrm{g} / \mathrm{mL}\right)^{3}$ we reported the synthesis of $\mathrm{Cl} 2-\mathrm{Cl} 77^{\text {ta }} \mathrm{C} 3-\mathrm{Cl1}$, and $\mathrm{Cl}-\mathrm{C} 11^{\text {to }}$ fragments of amphidinolide $\mathrm{O}(\mathbf{1})$ for the past few years. We report herein a new synthetic route to CI-CII fragnent 4 of amphidinolide $\mathrm{O}$ (1) via a ring-opening reaction of epoxide 5 by dithiane 6 as a key step.

In a retrosynthetic point of view (Scheme 1). the amphidi-

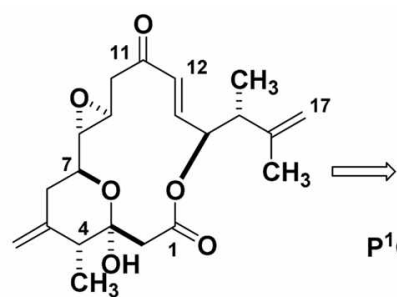

Amphidinolide $O$ (1)

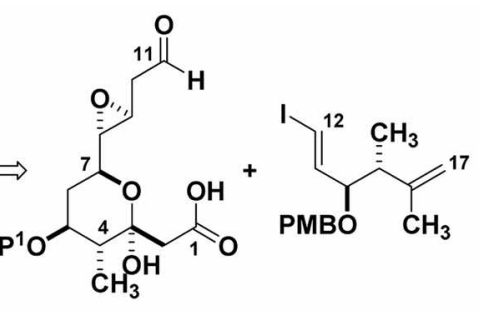

3

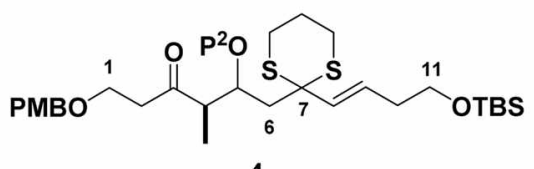

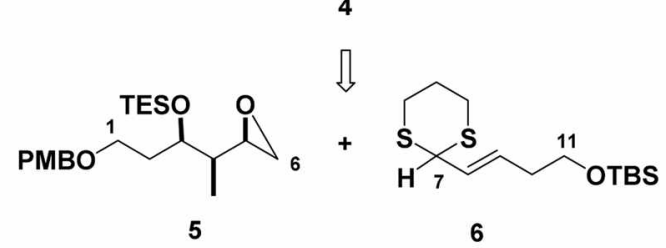

Scheme 1. Retrosynthesis of amphidinolide $O(1)$.

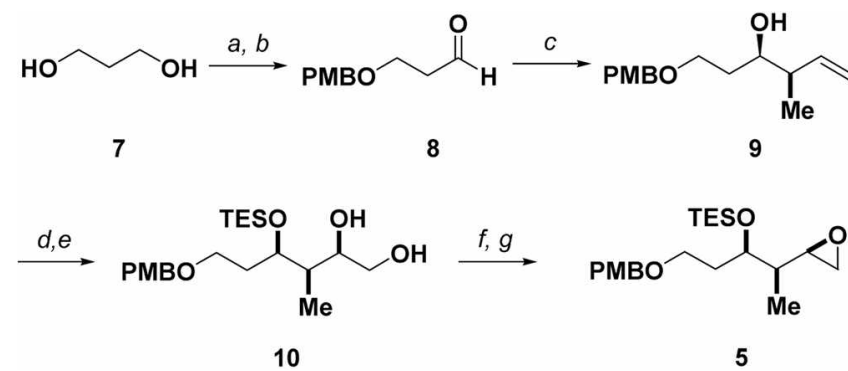

Scheme 2. Synthesis of Cl-C6 epoxide fragment 5 . (a) $\mathrm{NaH}$ PMBCl, THF, $70^{\circ} \mathrm{C}$, 5 day, $84 \%$, (b) DMSO, (COCl h, $\mathrm{CH}_{2} \mathrm{Cl}_{2}$ $\mathrm{Et}_{3} \mathrm{~N},-78$ " $\mathrm{C}, 99 \%$, (c) $t$-BuOK, cis-2-butene, $n$-BuLi, THF, -78 ${ }^{\circ} \mathrm{C}, 5 \mathrm{~min}$, then $-45^{\circ} \mathrm{C}, 20 \mathrm{~min}$ ( - )-Ips. BOMe, $-78^{\circ} \mathrm{C}, 40 \mathrm{~min}$, then $\mathrm{BF}_{3} \mathrm{OEt}_{2}, 8,-78{ }^{\circ} \mathrm{C}, 3 \mathrm{hr}$. $3 \mathrm{~N} \mathrm{NaOH}, 30 \% \mathrm{H}_{2} \mathrm{O}_{2}, 72 \%$, (d) TESCl, DMAP, prr, rt, 6 hr, 99\%; (e) AD-mix $\beta, t-B u O H, \mathrm{H}_{2} \mathrm{O}$, rt, $12 \mathrm{hr}, 83 \%$; (f) TsCl, DMAP, $\mathrm{Et}_{3} \mathrm{~N}, \mathrm{CH}_{2} \mathrm{Cl}_{2}, \mathrm{rt}, 6 \mathrm{hr}, 88 \%$; (g) DBU, $\mathrm{CH}_{2} \mathrm{Cl}_{2}, \mathrm{rt}, 90 \mathrm{~min}, 72 \%$

nolide $O$ (1) can be dissected into two fragments. the C.lCll fragment 2 bearing the epoxide and the hemiketal moieties and the C12-C.17 vinyl iodide fragment $3{ }^{\text {ta }}$ The hemiketal 2 would be derived from the acyclic precursor 4 . and the precursor 4 could be cleaved into the epoxide 5 and dithiane $\mathbf{6}$. The intermediate 5 and $\mathbf{6}$ would be prepared from a common starting material. 1,3-propanediol (7).

The synthesis of the C.1-C.6 epoxide was summarized in Scheme 2. Monoprotection of the diol 7 as a PMB ether using sodium lydride and $\mathrm{PMBCl}$ in THF was followed by Swern oxidation to afford the aldehyde 8 in $83 \%$ two-step yield. Diastereoselective crotylation of aldehy de 8 by in-sin generated $(Z)-(-)$-Ipc 3 B-croțl reagent proceeded efficiently to produce the alcohol 9 in $72 \%$ yield. ${ }^{5}$ Protection of the hydroxy group of 9 by treatment of TESCl and DMAP in $99 \%$ yield and Sharpless asymmetric diltydrosylation of the terminal double bond in $83 \%$ yield ${ }^{6}$ provided the diol $\mathbf{1 0}$. Finally. the 1.2-diol 10 was transfonmed into the epoxide 5 wa a two-step sequence. tosylation of primary alcohol with tosyl chloride and DMAP in TEA/CH $\mathrm{Cl}_{2}(1: 1)$ and subsequent cyclization with $\mathrm{DBU}$ in $\mathrm{CH}_{2} \mathrm{Cl}_{2}{ }^{7}$ in $63 \%$ overall yield.

The C7-C 11 fragnent 6 was prepared as shown in Scheme 3. 1.3-Propanediol (7) was treated with $t$-buty ldimethy lsilyl 


$$
\overbrace{7}^{\mathrm{HOH}} \stackrel{a}{\longrightarrow} \overbrace{11} \overbrace{\mathrm{OTBS}} \stackrel{b, c}{\longrightarrow} \mathrm{EtO}_{12}^{\mathrm{O}}
$$

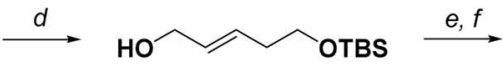

13

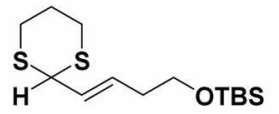

Scheme 3. Synthesis of $\mathrm{C} 7-\mathrm{Cll}$ dithiane tragment 6 . (a) TBSCl, imidazole, $\mathrm{CH}_{2} \mathrm{Cl}_{2}$, it, 3 dav, $72 \%$; (b) DMSO, (COCl), $\mathrm{CH}_{2} \mathrm{Cl}_{2}$, $\mathrm{Et}_{3} \mathrm{~N},-78^{\circ} \mathrm{C}, 99 \%$; (c) $\mathrm{Ph}_{3} \mathrm{P}=\mathrm{CHCO} \mathrm{Et}_{2}$, toluene, $45^{\circ} \mathrm{C}, 1$ hr, $89 \%$ : (d) DIBAL, $\mathrm{CH}_{2} \mathrm{Cl}_{2},-78{ }^{\circ} \mathrm{C}, \mathrm{l}$ hr, $91 \%$; (e) DMSO, $(\mathrm{COCl}$ ), $\mathrm{CH}_{2} \mathrm{Cl}_{2}, \mathrm{Et}_{3} \mathrm{~N},-78^{\circ} \mathrm{C}, 99 \%$; (f) 1,3-propanedithiol, $\mathrm{Mg}\left(\mathrm{ClO}_{4}\right)_{2}$, ether, $\mathrm{rt}, 12 \mathrm{hr}, 62 \%$.

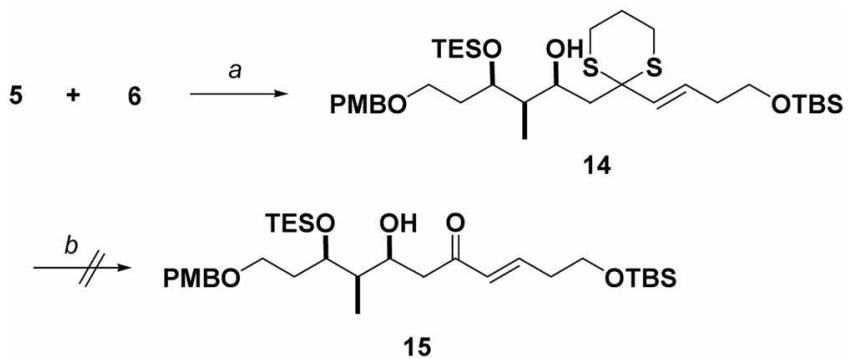

Scheme 4. Coupling of intemediate 5 and 6. (a) (1) 6, n-BuLi, $\mathrm{THF},-78^{\circ} \mathrm{C}, 20 \mathrm{~min} ;-20^{\circ} \mathrm{C}, 40 \mathrm{~min}$ (ii) $5,-78^{\circ} \mathrm{C},-20^{\circ} \mathrm{C}, 1 \mathrm{hr}$, $62 \%$. (b) Keaction conditions (see the text for details).

chloride and imidazole to afford the primary alcohol 11 in $72 \%$ yield. Swen oxidation of $\mathbf{1 1}$ and subsequent Wittig reaction produced trans-a, $\beta$-unsaturated ester 12 in $88 \%$ overall yield. And the ester 12 was converted to allylic alcohol 13 by reduction with DIBAL at $-78^{\circ} \mathrm{C}$ in $91 \%$ yield. The alcohol 13 was then oxidized quantitatively using Swern protocol and the resulting aldehyde was protected immediately with 1,3-propanedithiol using $\mathrm{Mg}\left(\mathrm{ClO}_{4}\right)_{2}$ in ether to complete the synthesis of 6 in $62 \%$ yield.

With key intermediates 5 and 6 in our hands. coupling of 5 and 6 for the synthesis of acyclic precursor 14 was carried out immediately by $n$-BuLi in THF in $62 \%$ yield (Scheme 4). ${ }^{9}$ However. funal elaboration to deprotect the 1,3-dithiane moiety using standard reaction conditions such as MeI. NCS. NBS. $\mathrm{Hg}\left(\mathrm{ClO}_{4}\right)_{2}$, or $\mathrm{AgNO}_{3}$ failed to provide the desired ketone 15. Starting material 14 was recovered or decomposed $^{(1)}$ in every case and further investigations on this issue will be in progress.

In summary. starting from 1,3-propanediol (7). we have prepared epoxide 5 via 7 -step sequence in $31 \%$ overall yield and dithiane 6 via 6 -step sequence in $35 \%$ overall yield. Although the coupling of 5 and 6 was achieved easily in $62 \%$ yield. deprotection of the dithiane moiety was not successful so far.

Acknowledgement. This research was assisted funancially by Sogang University Research Grant of 2003 (20031030).

\section{References}

1. (a) Lam. H. W.: Pattenden. G. Angew. Chem. Int Ed Engl. 2002. 41. 508-511. (b) Kim. C. H.; An. H. J:- Shin. W. K.; Yu. W. Woo. S. K.: Jung. S. K.: Lee. E. Angew. Chent. Int. Ed. Engl 2006. 45. 8019-8021. (c) Furstner. A.: Bouchez. L. C.: Funel. J. A.: Liepit1s. V: Poree. F. H.: Gilmour. R.: Beaufils. F.: Laurich. D.: Tamiya. M. Angew. Chem. Int Ed. Engl 2007. 46. 9265-9270. (d) Petri. A. F; Schneekloth, J. S., Jr; Mandal. A. K; Crews. C. M. Org. Latt. 2007. 9. 3001-3004. (e) Williams, D. R.: Kissel. W. S. J. Am. Chem Soc. 1998. 120. 11198-11199. (f) Williams. D. R.: Meyer. K. G. J. Am. Chent Soc. 2001. 123. 765-766. (g) Williams. D. R.: Myers. B. T.: Mi. L. Org. Lett. 2000. 2. 945-948. (hi) Furstner. A.: Aissa. C.: Riveiros, R.: Ragot, J. Angew: Chem. Int Ed. Engl. 2002. 41. 4763-4766. (i) Ghosh. A. K: Gong. G. J. Am. Chem. Soc. 2004. 126, 3704-3705. (j) Jin, J.: Chen. Y.: Li. Y; Wu, J.; Dai. W.M. Org. Lett 2007 . 9. 2585-2588.

2. (a) Lee. D. H.: Lee. S. W. Tetrahedron Lett 1997. $38,7909-7910$ (b) Lee. D. H.: Rho. M. D. Tetrohedron Lett. 2000. H1. 2573-2576. (c) Ishiyama. H.: Ishibashi, M.: Kobayashi, J. J. Chem. Hham. Bull. 1996. H4. 1819-1822. (d) Shotwell, J. B; Roush. W. R. Org Lett. 2004. 6, 3865-3868. (e) Chakraborty, T. K.; Suresh, V. R. Tetrahedron Le't. 1998. 39.9109-9112.

3. Ishibashi. M.: Takahashi. M.: kobayashi. T. J. Org. Chem. 1995. $60.6022-6066$.

4. (a) Pang. J. H. Lee, D. H. Bull. Kor: Chem. Soc, 2002. $23,1173-$ 1176. (b) Pang. J. H. Ham. Y. J.: Lee, D. H. Bull. Kor: Chem. Soc. 2003. 24. 891-892. (c) Jang, M. Y.: Kim. J. W.: Lee, D. H. Bull. Kon Chem. Soc. 2005. 26. 1497-1498.

5. Xu. S. L:: Xia. H.: Moore. H. W. J. Ong. Chem. 1991. 56. 60946103.

6. Kolb, H. C. VanNieuwenhze. M. S.: Sharpless, K. B. Chem. Rev 1994. 94, 2483-2547.

7. (a) Huerou, y. L.: Doyon. J.: Gree. R. L. J. Org. Chem. 1992, 57. 5383-5394. (b) Corey. E. T.: Helal. C. T. Tetrahedron Lett. 1993. $3+.5227-5230$.

8. Tietze. L. F.: Weigand. B.: Wulffi. C. Smhesis 2002 28. 69-71.

9. Tan, C. H.: Kobayashi. Y.: Kishi, Y. Org. Lett. 1999. 1. 2177. 2180 .

10. (a) Sunazukia, $T$ : Shirahata. T: Yoshida K.: Yamamoto. D: Harigaya. Y.: Nagai. T.: Kiyohata. I.: Yamada. H.: Kuwajima. I:: (Imura. S. Tetrahedion Lett. 2002. 43. 1265-1268. (b) Rodriguez. S.: Camps. F.: Fabrias. G. J. Org. Chem. 2001. 66. 8052-8058. (c) Toshima, K.; Jyojima, T.: Yoshida, T.: Murase, H.: Nakata, M: Matsumura, S. J. Org. Chem. 1997, 62. 3271-3284. (d) Tsuboi. K: Ichikawa, Y: Jiang. Y; Naganawa, A.: Isobe. M. Tetrahedron 1997. $53.5123-5142$. 